\title{
Antioxidants Vitamin C and Vitamin E for the Prevention and Treatment of Cancer
}

\author{
Ian D. Coulter, PhD, 1,2,3,6 Mary L. Hardy, MD, ${ }^{1,4}$ Sally C. Morton, PhD, ' Lara G. Hilton, ${ }^{1}$ \\ Wenli Tu, MS, ${ }^{7}$ Di Valentine, JD, ${ }^{7}$ Paul G. Shekelle, MD ${ }^{1,5,6}$ \\ 'RAND, Southern California Evidence-based Practice Center, Santa Monica, CA, USA; ${ }^{2}$ School of Dentistry, University of California Los \\ Angeles, Los Angeles, CA, USA; ${ }^{3}$ Southern California University of Health Sciences, Los Angeles, CA, USA; ${ }^{4}$ Cedars-Sinai Integrative \\ Medicine Medical Group Inc., Los Angeles, CA, USA; ${ }^{5}$ RAND, Greater Los Angeles VA Healthcare System, Los Angeles, CA, USA; ${ }^{5}$ Samueli \\ Institute for Information Biology, Alexandria, VA, USA.
} OBJECTIVE: To evaluate the evidence of the supplements vitamin $\mathrm{C}$
and vitamin $\mathrm{E}$ for treatment and prevention of cancer.

METHODS: Systematic review of trials and meta-analysis.

DATA SOURCES AND MAIN RESULTS: Thirty-eight studies showed scant evidence that vitamin $\mathrm{C}$ or vitamin $\mathrm{E}$ beneficially affects survival. In the ATBC Cancer Prevention Study Group, no statistically significant effect of treatment was seen for any cancer individually, and our pooled relative risk (regardless of tumor type) for $\alpha$-tocopherol alone was 0.91 (95\% confidence interval [CI]: $0.74,1.12$ ). All cause mortality was not significant. In the Linxian General Population Trial, the relative risks for cancer death for vitamin $\mathrm{C}$ (combined with molybdenum) was 1.06 (95\% CI: $0.92,1.21$ ) and for vitamin $\mathrm{E}$ (combined with $\beta$-carotene and selenium) was 0.87 (95\% CI: 0.76, 1.00). We identified only 3 studies that reported statistically significant beneficial results: vitamin $\mathrm{C}$ (in combination with BCG) was found to be beneficial in a single trial of bladder cancer and vitamin $\mathrm{E}$ (in combination with $\omega-3$ fatty acid) increased survival in patients with advanced cancer. In the ATBC trial, in analyses of 6 individual cancers, the prevention of prostate cancer in subjects treated with $\alpha$-tocopherol was statistically significant $(\mathrm{RR}=0.64,95 \% \mathrm{CI}: 0.44,0.94)$.

CONCLUSIONS: The systematic review of the literature does not support the hypothesis that the use of supplements of vitamin $\mathrm{C}$ or vitamin $\mathrm{E}$ in the doses tested helps prevent and/or treat cancer in the populations tested. There were isolated findings of benefit, which require confirmation.

KEY WORDS: vitamin C; vitamin E; systematic review; cancer; antioxidant.

DOI: $10.1111 /$ j.1525-1497.2006.0483.x

J GEN INTERN MED 2006; 21:735-744.

$\mathrm{T}$ he April 2000 National Academy of Sciences/Institute of Medicine/Food and Nutrition Board report entitled Dietary Reference Intakes for Vitamin C, Vitamin E, Selenium, and Carotenoids defined the term dietary antioxidant, provided Dietary Reference Intakes (DRIs) for the antioxidant vitamins and minerals, and reviewed the evidence supporting a role for these nutrients in preventing or treating a variety of chronic diseases. A dietary antioxidant is a substance in foods that significantly decreases the adverse effects of reactive species, such as reactive oxygen and nitrogen species, on normal physiological functions in humans. ${ }^{1}$ The discovery of the vitamins and their requirements in human nutrition were based on findings that the omission of these substances from the diet

None of the authors have any conflicts of interest to declare.

Address correspondence and requests for reprints to Dr. Coulter: 1776 Main Street, PO Box 2138, Santa Monica, CA 90407-2138 (e-mail: coulter@rand.org). resulted in the acute appearance of constellations of symptoms. It has long been argued that the adequacy of the vitamin supply to cells and tissues influences the development, progress, and outcome of cancers. ${ }^{2}$

The committee that authored the report found laboratory and epidemiological evidence that diets rich in fruits and vegetables (foods that are high in antioxidants) may be associated with the prevention of certain types of cancer, but found a lack of scientific basis for recommendations regarding any specific nutrient supplement. ${ }^{3}$ However, supplemental antioxidants have been promoted to help prevent cancer. A recent review concluded that vitamin supplementation "may contribute to a reduced risk of cancer." 4 To help inform primary care physicians on this topic we performed a systematic review and meta-analysis to assess the evidence regarding the use of supplemental vitamin $\mathrm{C}$ and/or vitamin $\mathrm{E}$ to prevent and treat cancer.

\section{DATA SOURCES}

Potential evidence for the article came from several sources: online library databases, the reference lists of all relevant articles, and experts and the personal libraries of project staff and their associates. "Grey" literature was included (abstracts, etc.) but we did not specifically search for unpublished data. The team also reviewed meta-analyses and systematic reviews. Limiting the output to human studies, we searched using the terms vitamin $\mathrm{E}$, vitamin $\mathrm{C}$, and their many pharmacological synonyms. The synonyms and databases utilized are displayed in Table 1.

\section{REVIEW METHODS}

This article is part of a larger review of the literature regarding the antioxidants vitamin $\mathrm{C}$, vitamin $\mathrm{E}$, and coenzyme $\mathrm{Q} 10 .^{5}$ This article reports on findings of vitamin $\mathrm{C}$ and vitamin $\mathrm{E}$ for cancer. No trials were found for coenzyme $\mathrm{Q} 10$ and cancer. Two reviewers independently evaluated and removed duplicated titles. One reviewer is a medical sociologist at RAND with 30 years of CAM research and an expert on systematic reviews and the other reviewer is a physician and director of the Cedars-Sinai Integrative Medicine Medical Group and a CAM expert. Language was not considered a barrier to inclusion. To be clear about our terminology: a "trial" refers to a controlled clinical trial; a "study" refers to a presentation of a specific 
Table 1. Data Sources and Search Strategy

\section{Terms Used}

Vitamin C

Vitamin E

Thirteen biomedical databases were searched through early 2002
Ascorbic acid (exploded) from Medline, Embase OR ascorbic acid from all other databases OR dehydroascorbic acid* OR ascorbate OR vitamin C OR antiscorbutic vitamin* OR cevitamic acid* AND neoplasms (exploded) from Medline OR malignant neoplastic disease (exploded) from Embase OR (cancer OR neoplasm*) in subject heading field from BIOSIS OR cancer* in title or subject heading field from all other databases OR neoplasm* from all other databases (exception-in CancerLit the terms for cancer were omitted and just the total of the "vitamin C" terms were used) AND (prevention OR preventive OR therapy OR therapeutic OR treatment) in title, subject heading fields AND human (Exploded) from Medline OR vitamin E OR $\alpha$ tocopherol* OR D1 $\alpha$ tocopherol* OR d $\alpha$ tocopherol OR $\operatorname{rrr} \alpha$ tocopherol* OR all rac $\alpha$ tocopherol* AND neoplasms (exploded) from Medline OR malignant neoplastic disease (exploded) from Embase OR (cancer OR neoplasm*) in subject heading field from BIOSIS OR cancer* in title or subject heading field from all other databases OR neoplasm* from all other databases (exception-in CancerLit the terms for cancer were omitted and just the total of the "vitamin E" terms were used) AND (prevention OR preventive OR therapy OR therapeutic OR treatment) in title, subject heading fields AND human

Allied and Complementary Medicine, BIOSIS Previews ${ }^{\mathbb{R}}, \mathrm{CAB}_{\mathrm{HEALTH}}{ }^{\mathbb{R}}, \mathrm{CANCER}^{\mathrm{LIT}}{ }^{\mathbb{R}}$, Cochrane Library, Elsevier Biobase, EMBASE, MANTIS ${ }^{\mathrm{TM}}$, MEDLINE ${ }^{\mathbb{R}}$, SciSearch ${ }^{\circledR}$ Cited Ref Sci 1974 to 1989 , Social SciSearch ${ }^{\mathbb{R}} 1972$ to 2002, SciSearch ${ }^{\mathbb{R}}$ Cited Ref Sci. Languages other than English were included in the search and the review portion of a trial's results, e.g., focused on 1 outcome or at a particular follow-up time; and a "published article" refers to a published document. Some published articles may contain more than 1 study, particularly if they contain results from more than 1 trial. Some trials, especially large ones, have many associated studies and articles.

\section{Data Extraction}

Two individuals independently reviewed each article, abstracted data regarding design, population, intervention and outcomes, and resolved disagreement by consensus.

To evaluate the quality of the trials, we collected information on the study design, appropriateness of randomization, blinding, description of withdrawals and dropouts and concealment of allocation. ${ }^{6}$ A score for quality was calculated for each trial using a system developed by Jadad et al. ${ }^{7}$ Empirical evidence in other settings has shown that studies scoring 2 or less report exaggerated results compared with studies scoring 3 or more. ${ }^{8}$ All Jadad scores are displayed in the evidence table in Appendix A.

\section{Choice of Outcomes}

The grouping of treatments and the appropriate comparison group, e.g., any combination of vitamins with vitamin $\mathrm{E}$ versus placebo, was based on clinical knowledge and was decided a priori. The 4 clinically relevant dichotomous outcomes that were reported in sufficient quantity to justify data synthesis were death, development of new tumors in subjects with no prior tumor history, progression of existing tumors, and development of new adenomatous colonic polyps with vitamin $\mathrm{E}$.

\section{Data Synthesis}

For each of the above outcomes, we estimated the log risk ratio comparing the relevant treatment group to either placebo or another comparison group as appropriate. We estimated the standard error of the log risk ratio and constructed a 95\% confidence interval (CI). We conducted the analysis on the log scale to stabilize the variance, and present the results on the risk ratio scale for interpretability. A risk ratio smaller than 1 indicates that a lower risk of the outcome is associated with the treatment of interest as compared with the comparison treatment, e.g., placebo. For death and new tumors, the trials were too heterogeneous to pool meta-analytically.

Three large trials ${ }^{11-13}$ were too different in terms of study population and length of follow-up both from each other and from the other small trials and were not included in our metaanalysis, nor did we aggregate related outcomes within them. For the other small trials, we aggregated deaths because of different types of cancers and conducted a risk ratio analysis as described above.

We estimated a DerSimonian and Laird ${ }^{14}$ random effects pooled log risk ratio for any subgroup of 3 or more trials that had similar designs and comparison groups, and that measured colonic polyps for a particular cancer over similar followup periods. We present the pooled result on the risk ratio scale for interpretation, the $\chi^{2}$ test for heterogeneity $P$-value, ${ }^{15}$ and a forest plot. In this plot, each individual risk ratio is shown with its CI as a box whose area is inversely proportional to the estimated study variance. The pooled risk ratio and its CI are shown as a diamond at that bottom of the plot with a dotted vertical line indicating the pooled estimate. A vertical solid line at a risk ratio of 1 indicates no treatment effect.

For each subgroup of studies for which we conducted a meta-analysis, we assessed the possibility of publication bias by evaluating a funnel plot of the log risk ratios graphically for asymmetry resulting from the nonpublication of small, negative studies. Because graphical evaluation can be subjective, we also conducted an adjusted rank correlation test ${ }^{16}$ and a regression asymmetry test ${ }^{17}$ as formal statistical tests for possible publication bias.

\section{RESULTS}

The flow of articles is displayed in Figure 1. From 357 articles accepted after the initial title screening, we identified 36 articles for further review. Two articles ${ }^{18,19}$ described 2 different studies, so a total of 38 unique studies were referred for detailed review. Many of these published articles reported on the $\alpha$-tocopherol, $\beta$-carotene Cancer Prevention Study Group (ATBC Trial), the Linxian General Population Trial, and the 


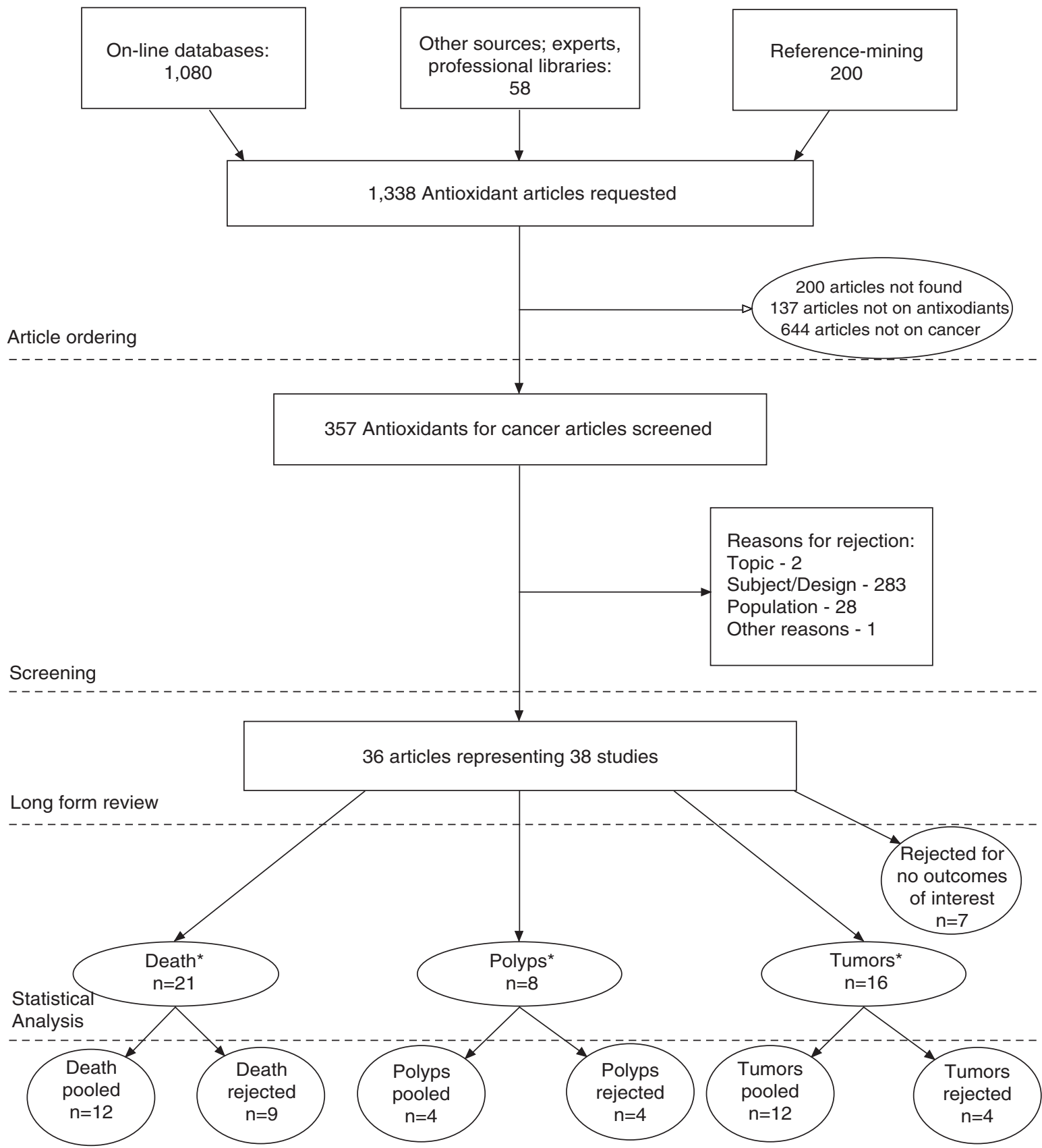

*Studies may be included in more than one analysis

FIGURE 1. Literature flow.

Linxian Dysplasia Group Trial. The key features of these large trials are provided in Table 2.

\section{Description of the Evidence}

We identified 21 studies that reported death as a primary outcome; 16 that reported on new tumor development; 8 studies focused on the development of colonic polyps; and 7 studies reported on a variety of intermediate outcomes. An individual study may have contributed to more than 1 analysis.

\section{Analysis of Studies Reporting on Death}

Twenty-one studies reported the outcome of cancer-related death $^{12,18,19,21-34}$ (with some articles reporting on more than 1 study). Twelve studies discussed below contributed to the analyses. Nine were excluded because they did not report deaths by group or only reported survival curves. ${ }^{18,19,24-26,29}$ Descriptions of these studies can be seen in the evidence table in Appendix A. Descriptions of these studies can also be obtained at http://www.ahrq.gov/clinic/evrptpdfs.htm under the title: Antioxidant Supplements, Prevention and Treatment of Cancer. Of the excluded studies, only the study by Gogos et al. $^{26}$ reported a benefit: the group receiving vitamin $\mathrm{E}$ in 
Table 2. Summary of Large Clinical Trials Included in Pooled Analyses*

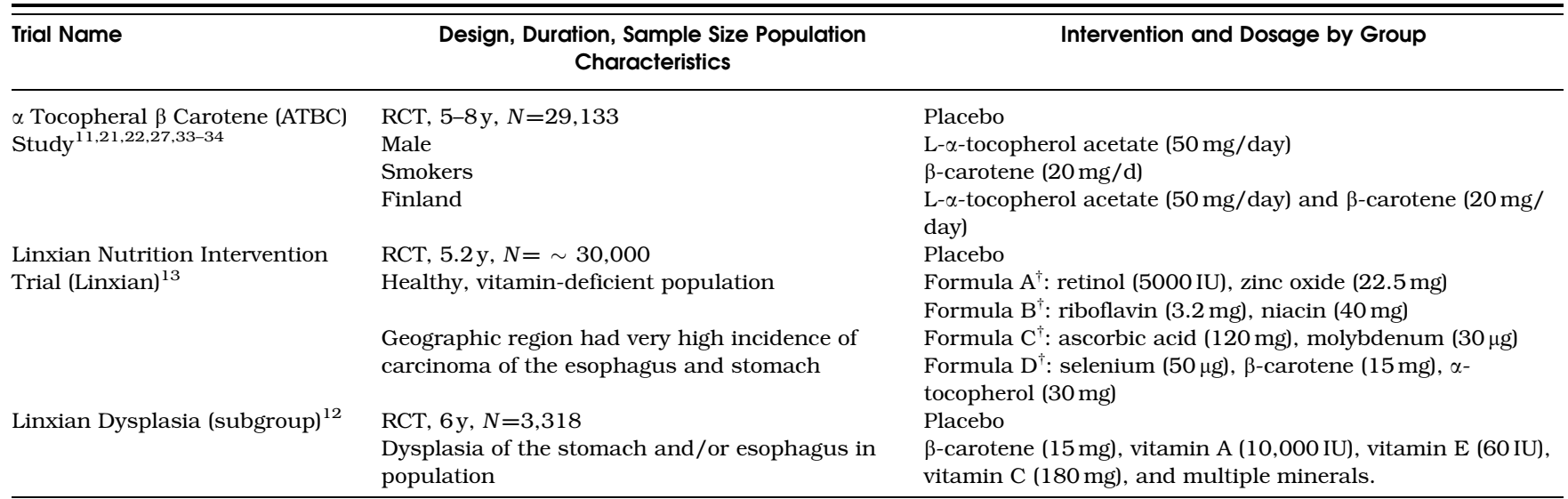

${ }^{*}$ Data on vitamin $E$ dosages, which were often in the form of $\alpha$-tocopherol, are sometimes reported in milligrams and sometimes in international units (IU). One milligram of $\alpha$-tocopherol is approximately equal to $1.5 \mathrm{IU}$ of vitamin $\mathrm{E}$.

'Each of these formulas was given alone and in combination with the other formulas.

combination with fish oil had prolonged survival $(P<.03)$ compared with placebo.

\section{Death Analysis from the ATBC Trial}

From published articles from the ATBC Trial, risk ratios were calculated for lung, ${ }^{11,21}$ prostate, ${ }^{27}$ colorectal, ${ }^{22}$ urothelial, ${ }^{34}$ and renal cell cancers. ${ }^{34}$ Death from prostate cancer had the greatest relative risk reduction in the groups receiving $\alpha$-tocopherol alone and in combination with $\beta$-carotene, although statistically insignificant. ${ }^{27}$ None of the studies individually showed a statistically significant effect. We calculated risk ratios for a combined death outcome, regardless of tumor type, for the 3 ATBC studies that reported their results for all 4 arms (we do not consider this a meta-analysis because results are not pooled across trials). ${ }^{21,22,34}$ Again these results are not statistically significant. The principal report from the ATBC Trial combined arms so that results for all cause death were reported as all arms using $\alpha$-tocopherol versus arms without $\alpha$-tocopherol. ${ }^{11}$ This risk ratio was statistically insignificant. A single additional study, ${ }^{33}$ which reported on mortality from pancreatic cancer, likewise did not show statistical significance when risk ratios were calculated. The results of the ATBC cancer death outcomes risk ratio calculations are summarized in Table 3.

\section{Death Analysis from the Linxian Trials}

In the Linxian General Population Trial the intervention was placebo or 1 or more of the following formulas: $A=$ retinol (5,000 IU), zinc oxide ( $22.5 \mathrm{mg}), \mathrm{B}=$ riboflavin $(3.2 \mathrm{mg})$, niacin (40 mg), $\mathrm{C}=$ ascorbic acid (120 mg), molybdenum (30 $\mu \mathrm{g}$ ), and $\mathrm{D}=$ selenium $(50 \mu \mathrm{g}), \beta$-carotene ( $15 \mathrm{mg}), \alpha$-tocopherol (30 mg). For the Linxian Dysplasia Subgroup the intervention was placebo or a supplement of $\beta$-carotene $(15 \mathrm{mg})$, vitamin A (10,000 IU), vitamin E (60 IU), vitamin C (180 mg), and multiple minerals.

Two studies from the Linxian Trials had adequate statistics for further analysis. Blot et al. ${ }^{13}$ report on the general Linxian population and $\mathrm{Li}$ et al. ${ }^{12}$ reported on the effect of the supplement intervention in the Dysplasia Group. The risk ra- tios calculated for all outcome for these studies are displayed in Table 4. In this trial, there is no evidence of a benefit for survival.

\section{Death Analysis from Trials Using Vitamin C for Cancer}

Four studies, including Lamm et al., ${ }^{28}$ the Heart Protection Study Collaboration Group, ${ }^{30}$ Nutrition Review, ${ }^{31}$ and Poulter et al., ${ }^{32}$ tested the efficacy of vitamin $\mathrm{C}$ for treatment and/ or prevention of patients with cancer and had sufficient statistics to proceed for further analysis. However, these trials were not pooled because of the heterogeneous nature of their populations and interventions. The results of this analysis are summarized in Table 5. For the interventions tested, in the populations described, there is no evidence for a benefit for survival.

\section{Analysis of Studies Reporting on New Tumor Development}

Sixteen studies, corresponding to 14 published articles, were considered for further analysis of the development of new tumors or recurrence of tumors. ${ }^{11,13,18,19,21,27-30,33-36}$ Four studies from the Linxian trials were excluded for inadequate statistics because the relative risks were reported as adjusted risk ratios and insufficient data were given to be able to convert them to unadjusted risk ratios and make the results comparable with those reported for other trials. ${ }^{13,18,19}$

\section{New Tumors Analysis from the ATBC Trial}

Seven studies of the ATBC trial reported on the development of a variety of new tumors. Results of this analysis are summarized in Table 6 . As with studies of death from cancer, 7 studies reported on the development of new specific tumors: lung, ${ }^{11,21}$ colorectal, ${ }^{22}$ prostate, ${ }^{27}$ pancreas, ${ }^{33}$ urothelial, $^{34}$ and renal cell cancers. ${ }^{34}$ Only the analysis of new prostate cancer reported a statistically significant association in the study by Heinonen. ${ }^{27}$ However, there was no statistically significant 
Table 3. Risk Ratios for Death Outcome from the ATBC Trial*

\begin{tabular}{|c|c|c|c|c|c|c|}
\hline Author (Year) & Type of death & Intervention ${ }^{\dagger}$ & $\begin{array}{l}\text { Sample } \\
\text { Size }\end{array}$ & $\begin{array}{l}\text { Follow } \\
\text { up }(y)\end{array}$ & $\begin{array}{l}\text { Total } \\
\text { Deaths }\end{array}$ & $\operatorname{RR}(95 \% \mathrm{Cl})$ \\
\hline \multirow[t]{2}{*}{ ATBC Trial $(1994)^{11}$} & \multirow[t]{2}{*}{ Lung cancer } & AT & 14,564 & \multirow[t]{2}{*}{6.1} & 285 & \multirow[t]{2}{*}{$1.02(0.87,1.20)$} \\
\hline & & No AT & 14,569 & & 279 & \\
\hline \multirow[t]{3}{*}{ Albanes $(1996)^{21}$} & \multirow[t]{3}{*}{ Lung cancer } & AT & 7,286 & \multirow[t]{3}{*}{6.1} & 125 & $0.93(0.73,1.19)$ \\
\hline & & $\mathrm{AT}+\mathrm{BC}$ & 7,278 & & 154 & $1.15(0.91,1.45)$ \\
\hline & & Placebo & 7,287 & & 134 & \\
\hline \multirow[t]{3}{*}{ Heinonen $(1998)^{27}$} & \multirow[t]{3}{*}{ Prostate cancer } & $\mathrm{AT}$ & 7,286 & \multirow[t]{3}{*}{6.1} & 11 & $0.61(0.29,1.29)$ \\
\hline & & $\mathrm{AT}+\mathrm{BC}$ & 7,278 & & 12 & $0.67(0.32,1.38)$ \\
\hline & & Placebo & 7,287 & & 18 & \\
\hline \multirow[t]{3}{*}{ Albanes $(2000)^{22}$} & \multirow[t]{3}{*}{ Colorectal cancer } & $\mathrm{AT}$ & 7,286 & \multirow[t]{3}{*}{6.1} & 12 & $1.09(0.48,2.47)$ \\
\hline & & $\mathrm{AT}+\mathrm{BC}$ & 7,278 & & 13 & $1.18(0.53,2.64)$ \\
\hline & & Placebo & 7,287 & & 11 & \\
\hline \multirow[t]{3}{*}{ Virtamo $(2000)^{34}$} & \multirow[t]{3}{*}{ Urothelial cancer } & $\mathrm{AT}$ & 7,286 & \multirow[t]{3}{*}{6.1} & 6 & $1.20(0.37,3.93)$ \\
\hline & & $\mathrm{AT}+\mathrm{BC}$ & 7,278 & & 8 & $1.60(0.52,4.89)$ \\
\hline & & Placebo & 7287 & & 5 & \\
\hline \multirow[t]{3}{*}{ Virtamo $(2000)^{34}$} & \multirow[t]{3}{*}{ Renal cell cancer } & AT & 7286 & \multirow[t]{3}{*}{6.1} & 11 & $0.79(0.36,1.73)$ \\
\hline & & $\mathrm{AT}+\mathrm{BC}$ & 7,278 & & 10 & $0.72(0.32,1.61)$ \\
\hline & & Placebo & 7,287 & & 14 & \\
\hline \multirow{3}{*}{$\begin{array}{l}\text { Pooled analysis Albanes }(1996,2000)^{21,22} \\
\text { Virtamo }(2000)^{34}\end{array}$} & \multirow{3}{*}{$\begin{array}{l}\text { Combined cancer (lung, colorectal, } \\
\text { urothelial, and renal cell) }\end{array}$} & AT & 7,286 & \multirow[t]{3}{*}{6.1} & 165 & $0.91(0.74,1.12)$ \\
\hline & & $\mathrm{AT}+\mathrm{BC}$ & 7,278 & & 197 & $1.08(0.89,1.32)$ \\
\hline & & Placebo & 7,287 & & 182 & \\
\hline \multirow[t]{2}{*}{ ATBC Trial $(1994)^{11}$} & \multirow[t]{2}{*}{ All cause } & AT & 14,564 & \multirow[t]{2}{*}{6.1} & 1798 & $1.02(0.96,1.08)$ \\
\hline & & No AT & 14,569 & & 1768 & \\
\hline \multirow[t]{2}{*}{ Rautalahti (1999) ${ }^{33}$} & Pancreas & $\mathrm{AT}$ & 14,564 & \multirow[t]{2}{*}{6.1} & 49 & $1.44(0.93,2.23)$ \\
\hline & Cancer & No AT & 14569 & & 34 & \\
\hline
\end{tabular}

*Additional studies for which RR could not be calculated are discussed in the text and displayed in the Evidence Table in Appendix A.

'AT, $\alpha$-tocopherol; BC, $\beta$-carotene; RR, risk ratios; $C I$, confidence interval.

association reported in the reduction of new prostate cancer in the patients taking vitamin $\mathrm{E}$ and $\beta$-carotene, or a reduction in death from prostate cancer in either group.
We combined the tumor outcomes of the 5 studies that reported on results by separate arms ${ }^{21,22,27,33,34}$ regardless of tumor type. For $\alpha$-tocopherol versus placebo and for $\alpha$-tocop-

Table 4. Risk Ratios for Death Outcome from Linxian Trials*

\begin{tabular}{|c|c|c|c|c|c|c|c|}
\hline Study & Author (Year) & Type of Death & Intervention ${ }^{\dagger}$ & Sample Size & Follow up (y) & \# of Deaths & RR $(95 \% \mathrm{Cl})$ \\
\hline \multirow[t]{6}{*}{ Linxian Dysplasia } & \multirow[t]{2}{*}{$\operatorname{Li}(1993)^{12}$} & \multirow[t]{2}{*}{ All cause } & Supplement & 1,657 & 6 & 157 & $0.94(0.77,1.16)$ \\
\hline & & & Placebo & 1,661 & & 167 & \\
\hline & \multirow[t]{2}{*}{$\operatorname{Li~}(1993)^{12}$} & \multirow[t]{2}{*}{ cancer } & Supplement & 1,657 & & 87 & $0.98(0.74,1.31)$ \\
\hline & & & Placebo & 1,661 & & 89 & \\
\hline & \multirow[t]{2}{*}{$\operatorname{Li~(1993)~}{ }^{12}$} & \multirow{2}{*}{$\begin{array}{l}\text { Esophageal } \\
\text { cancer }\end{array}$} & Supplement & 1,657 & & 38 & $0.87(0.56,1.33)$ \\
\hline & & & Placebo & 1,661 & & 44 & \\
\hline \multirow[t]{24}{*}{ Linxian General Population } & \multirow[t]{12}{*}{ Blot $(1993)^{13}$} & \multirow[t]{12}{*}{ All cause } & $\mathrm{A}+\mathrm{B}$ & 3,701 & \multirow[t]{12}{*}{5.25} & 265 & $0.94(0.80,1.11)$ \\
\hline & & & $\mathrm{A}+\mathrm{C}$ & 3,694 & & 296 & $1.05(0.90,1.23)$ \\
\hline & & & $A+D$ & 3,703 & & 250 & $0.89(0.75,1.05)$ \\
\hline & & & $\mathrm{B}+\mathrm{C}$ & 3,691 & & 268 & $0.95(0.81,1.12)$ \\
\hline & & & $\mathrm{B}+\mathrm{D}$ & 3,699 & & 263 & $0.93(0.79,1.10)$ \\
\hline & & & $\mathrm{C}+\mathrm{D}$ & 3,705 & & 249 & $0.88(0.75,1.04)$ \\
\hline & & & $\mathrm{A}+\mathrm{B}+\mathrm{C}+\mathrm{D}$ & 3,712 & & 256 & $0.91(0.77,1.07)$ \\
\hline & & & Placebo & 3,679 & & 280 & \\
\hline & & & $\mathrm{C}$ & 14,802 & & 1,069 & $1.01(0.93,1.10)$ \\
\hline & & & No C & 14,782 & & 1,058 & \\
\hline & & & $\mathrm{D}$ & 14,819 & & 1,018 & $0.91(0.84,0.99)$ \\
\hline & & & No D & 14,765 & & 1,109 & \\
\hline & \multirow[t]{12}{*}{ Blot $(1993)^{13}$} & \multirow[t]{12}{*}{ Cancer death } & $\mathrm{A}+\mathrm{B}$ & 3,701 & \multirow[t]{12}{*}{5.25} & 94 & $0.87(0.66,1.15)$ \\
\hline & & & $\mathrm{A}+\mathrm{C}$ & 3,694 & & 121 & $1.13(0.87,1.45)$ \\
\hline & & & $\mathrm{A}+\mathrm{D}$ & 3,703 & & 81 & $0.75(0.57,1.00)$ \\
\hline & & & $\mathrm{B}+\mathrm{C}$ & 3,691 & & 101 & $0.94(0.72,1.23)$ \\
\hline & & & $\mathrm{B}+\mathrm{D}$ & 3,699 & & 103 & $0.96(0.73,1.25)$ \\
\hline & & & $\mathrm{C}+\mathrm{D}$ & 3,705 & & 90 & $0.84(0.63,1.10)$ \\
\hline & & & $\mathrm{A}+\mathrm{B}+\mathrm{C}+\mathrm{D}$ & 3,712 & & 95 & $0.88(0.67,1.16)$ \\
\hline & & & Placebo & 3,679 & & 107 & \\
\hline & & & C & 14,802 & & 407 & $1.06(0.92,1.21)$ \\
\hline & & & No $C$ & 14,782 & & 385 & \\
\hline & & & $D$ & 14,819 & & 369 & $0.87(0.76,1.00)$ \\
\hline & & & No $D$ & 14,765 & & 423 & \\
\hline
\end{tabular}

*Additional studies for which RR could not be calculated are discussed in the text and displayed in the Evidence Table in Appendix A.

$A$, retinol plus zinc; $B$, riboflavin plus niacin; $C$, vitamin $C$ (ascorbic acid) plus molybdenum; $D, \beta$-carotene plus vitamin $E$ and selenium, RR, risk ratio. 
Table 5. Risk Ratios for Death Outcome from Trials Using Vitamin C

\begin{tabular}{|c|c|c|c|c|c|c|c|}
\hline Study & Author (Year) & Type of death & Intervention & Sample Size & Follow up (y) & \# of Deaths & RR $(95 \% \mathrm{Cl})$ \\
\hline \multirow[t]{7}{*}{ Other trials } & $\operatorname{Lamm}(1994)^{28}$ & All cause & Megadose vitamins & 35 & 3.75 & 8 & $0.86(0.37,2.01)$ \\
\hline & & & RDA & 30 & & 8 & \\
\hline & Heart Protection Study, $2002^{30}$ & & Vitamins & 10,269 & 5 & 1,446 & $1.04(0.97,1.11)$ \\
\hline & Nutr Rev $(1985)^{31}$ & All cause & $\mathrm{C}$ & 25 & 1 & 51 & $1.04(0.69,1.57)$ \\
\hline & & & Placebo & 23 & & 49 & \\
\hline & Poulter $(1984)^{32}$ & All cause & $\mathrm{C}$ & 27 & 5 & 12 & $1.52(0.72,3.23)$ \\
\hline & & & Control & 24 & & 7 & \\
\hline
\end{tabular}

*Additional studies for which RR could not be calculated are discussed in the text and displayed in the Evidence Table in Appendix A.

$A$, retinol plus zinc; $B$, riboflavin plus niacin; $C$, vitamin $C$ (ascorbic acid) plus molybdenum; $D, \beta$-carotene plus vitamin $E$ and selenium.

herol with $\beta$-carotene versus placebo the results were not statistically significant.

Finally, Varis et al. reported on the risk of developing carcinoma (all cell types). For developing a new carcinoma the interventions $\alpha$-tocopherol alone and in combination with $\beta$-carotene showed no significant results.

\section{New Tumors Analysis from the Linxian Trial and Other Trials}

Three published articles from the Linxian Trials reported on the outcome of new tumor development. ${ }^{12,19,35}$ The General Population portion of the article by $\mathrm{Li}$ et al. ${ }^{19}$ reported on the development of new gastric and esophageal cancers, but could not be included in analysis because of insufficient statistics. Three studies ${ }^{12,19,35}$ reported data for similar outcomes from the Dysplasia portion of the Linxian Trial. No analysis reported a statistically significant benefit for reducing new tumor development (Table 7).

Two more published articles not connected to the ATBC or Linxian trials reported on the outcome of new tumor development. The study by Lamm et al. ${ }^{28}$ was a secondary prevention trial. It tested the effect of vitamin supplementation on the development of new bladder tumors in patients previously treated for transitional cell carcinoma of the bladder. The relative risk for the development of new bladder tumors was 0.50 (95\% confidence interval [CI]: 0.32, 0.78) favoring treatment with megadose vitamins compared with the recommended daily amount of vitamins. However, potentially confounding this result was that all groups also received BCG, which is known to promote the immune response to some other tumors. For the Heart Protection Study Collaboration Group $^{30}$ we calculated a relative risk which was statistically insignificant (Table 7).

Table 6. Risk Ratios for New Tumors from ATBC Trial*

\begin{tabular}{|c|c|c|c|c|c|c|}
\hline Author (Year) & Type of Tumor & Intervent & $\begin{array}{l}\text { n'Sample } \\
\text { size }\end{array}$ & $\begin{array}{l}\text { Follow- } \\
\text { up (y) }\end{array}$ & $\begin{array}{l}\text { Total New } \\
\text { Tumor }\end{array}$ & $\operatorname{RR}(95 \% \mathrm{Cl})$ \\
\hline ATBC $(1994)^{11}$ & Lung cancer & $\begin{array}{l}\text { AT } \\
\text { No AT }\end{array}$ & $\begin{array}{l}14,564 \\
14,569\end{array}$ & 6.1 & $\begin{array}{l}433 \\
443\end{array}$ & $0.98(0.86,1.11)$ \\
\hline Albanes $(1996)^{21}$ & Lung cancer & $\begin{array}{l}\mathrm{AT} \\
\mathrm{AT}+\mathrm{BC} \\
\text { Placebo }\end{array}$ & $\begin{array}{l}7,286 \\
7,278 \\
7,287\end{array}$ & 6.1 & $\begin{array}{l}204 \\
240 \\
208\end{array}$ & $\begin{array}{l}0.98(0.81,1.19) \\
1.16(0.96,1.39)\end{array}$ \\
\hline Albanes $(2000)^{22}$ & Colorectal cancer & $\begin{array}{l}\mathrm{AT} \\
\mathrm{AT}+\mathrm{BC} \\
\text { Placebo }\end{array}$ & $\begin{array}{l}7,286 \\
7,278 \\
7,287\end{array}$ & 6.1 & $\begin{array}{l}29 \\
30 \\
37\end{array}$ & $\begin{array}{l}0.78(0.48,1.27) \\
0.81(0.50,1.31)\end{array}$ \\
\hline Heinonen $(1998)^{27}$ & Prostate cancer & $\begin{array}{l}\text { AT } \\
\text { AT }+ \text { BC } \\
\text { Placebo }\end{array}$ & $\begin{array}{l}7,286 \\
7,278 \\
7,287\end{array}$ & 6.1 & $\begin{array}{l}43 \\
56 \\
67\end{array}$ & $\begin{array}{l}0.64(0.44,0.94) \\
0.84(0.59,1.19)\end{array}$ \\
\hline Rautalahti (1999) ${ }^{33}$ & Pancreas cancer & $\begin{array}{l}\text { AT } \\
\text { AT }+ \text { BC } \\
\text { Placebo } \\
\text { AT } \\
\text { no AT }\end{array}$ & $\begin{array}{r}7,286 \\
7,278 \\
7,287 \\
14,564 \\
14,569\end{array}$ & 6.1 & $\begin{array}{l}25 \\
26 \\
26 \\
51 \\
38\end{array}$ & $\begin{array}{l}0.96(0.56,1.66) \\
1.00(0.58,1.72) \\
1.34(0.88,2.04)\end{array}$ \\
\hline Virtamo $(2000)^{34}$ & Urothelial cancer & $\begin{array}{l}\mathrm{AT} \\
\mathrm{AT}+\mathrm{BC} \\
\text { Placebo }\end{array}$ & $\begin{array}{l}7,286 \\
7,278 \\
7,287\end{array}$ & 6.1 & $\begin{array}{l}47 \\
42 \\
37\end{array}$ & $\begin{array}{l}1.27(0.83,1.95) \\
1.14(0.73,1.77)\end{array}$ \\
\hline Virtamo $(2000)^{34}$ & Renal cell cancer & $\begin{array}{l}\mathrm{AT} \\
\mathrm{AT}+\mathrm{BC} \\
\text { Placebo }\end{array}$ & $\begin{array}{l}7,286 \\
7,278 \\
7,287\end{array}$ & 6.1 & $\begin{array}{l}27 \\
27 \\
27\end{array}$ & $\begin{array}{l}1.00(0.59,1.70) \\
1.00(0.59,1.71)\end{array}$ \\
\hline $\begin{array}{l}\text { Pooled analysis } \\
\text { Albanes }(1996,2000),{ }^{21,22} \text { Heinonen }(1998),{ }^{27} \\
\text { Rautalahti }(1999),{ }^{33} \text { Virtamo }(2000)^{34}\end{array}$ & $\begin{array}{l}\text { Combined types: } \\
\text { (lung, colorectal, prostate, pancreas, } \\
\text { urothelial, and renal cell) }\end{array}$ & $\begin{array}{l}\mathrm{AT} \\
\mathrm{AT}+\mathrm{BC} \\
\text { Placebo }\end{array}$ & $\begin{array}{l}7,286 \\
7,278 \\
7,287\end{array}$ & 6.1 & $\begin{array}{l}375 \\
421 \\
402\end{array}$ & $\begin{array}{l}0.93(0.81,1.07) \\
1.05(0.92,1.20\end{array}$ \\
\hline Varis $(1998)^{36}$ & Carcinoma & $\begin{array}{l}\mathrm{AT} \\
\mathrm{BC} \\
\mathrm{AT}+\mathrm{BC} \\
\text { Placebo }\end{array}$ & $\begin{array}{l}321 \\
329 \\
361 \\
333\end{array}$ & 6.1 & $\begin{array}{l}2 \\
3 \\
4 \\
2\end{array}$ & $\begin{array}{l}1.04(0.15,7.32) \\
1.52(0.26,9.03) \\
1.84(0.34,10.01)\end{array}$ \\
\hline
\end{tabular}

*Additional studies for which risk ratios could not be calculated are discussed in the text and displayed in the evidence table in Appendix A.

AT, $\alpha$-tocopherol; BC, $\beta$-carotene. 
Table 7. Risk Ratios for New Tumors from Linxian and Other Trials*

\begin{tabular}{|c|c|c|c|c|c|c|c|}
\hline Study & Lead Author (Year) & Type of Tumor & Intervention $^{\dagger}$ & Sample Size & Follow-up (y) & Total New Tumor & RR $(95 \% \mathrm{Cl})$ \\
\hline \multirow{18}{*}{$\begin{array}{l}\text { Linxian } \\
\text { Dysplasia }\end{array}$} & \multirow[t]{4}{*}{ Dawsey $(1994)^{35}$} & \multirow{4}{*}{$\begin{array}{l}\text { Esophageal } \\
\text { cancer }\end{array}$} & Supplement & 392 & \multirow[t]{2}{*}{2.5} & 16 & \multirow[t]{2}{*}{$0.78(0.41,1.49)$} \\
\hline & & & Placebo & 362 & & 19 & \\
\hline & & & Supplement & 195 & \multirow[t]{2}{*}{6} & 8 & \multirow[t]{2}{*}{$1.53(0.51,4.58)$} \\
\hline & & & Placebo & 186 & & 5 & \\
\hline & \multirow{4}{*}{ Dawsey $(1994)^{35}$} & \multirow[t]{4}{*}{ Gastric cancer } & Supplement & 43 & 2.5 & 13 & \multirow[t]{2}{*}{$1.63(0.75,3.52)$} \\
\hline & & & Placebo & 43 & & 8 & \\
\hline & & & Supplement & 202 & 6 & 18 & $0.91(0.49,1.68)$ \\
\hline & & & Placebo & 194 & & 19 & \\
\hline & \multirow[t]{4}{*}{ Dawsey $(1994)^{35}$} & \multirow[t]{4}{*}{ Overall biopsy } & Supplement & 400 & 2.5 & 29 & \multirow[t]{2}{*}{$0.99(0.60,1.64)$} \\
\hline & & & Placebo & 368 & & 27 & \\
\hline & & & Supplement & 202 & 6 & 23 & $0.92(0.54,1.57)$ \\
\hline & & & Placebo & 194 & & 24 & \\
\hline & \multirow[t]{2}{*}{$\operatorname{Li}(1993)^{12}$} & \multirow[t]{2}{*}{ All cancer } & Supplement & 1,657 & 6 & 227 & \multirow[t]{2}{*}{$1.03(0.87,1.22)$} \\
\hline & & & Placebo & 1,661 & & 221 & \\
\hline & \multirow[t]{2}{*}{$\mathrm{Li}(1993)^{12}$} & \multirow{2}{*}{$\begin{array}{l}\text { Esophageal } \\
\text { cancer }\end{array}$} & Supplement & 1,657 & 6 & 123 & \multirow[t]{2}{*}{$0.96(0.76,1.22)$} \\
\hline & & & Placebo & 1,661 & & 128 & \\
\hline & \multirow[t]{2}{*}{$\mathrm{Li}(1993)^{12}$} & \multirow{2}{*}{$\begin{array}{l}\text { Stomach } \\
\text { cancer }\end{array}$} & Supplement & 1,657 & 6 & 96 & \multirow[t]{2}{*}{$1.19(0.89,1.58)$} \\
\hline & & & Placebo & 1,661 & & 81 & \\
\hline \multirow[t]{8}{*}{ General } & \multirow[t]{4}{*}{ Taylor (1994) ${ }^{19}$} & \multirow{4}{*}{$\begin{array}{l}\text { Esophageal } \\
\text { cancer }\end{array}$} & $\mathrm{C}$ & 201 & 6 & 4 & \multirow[t]{2}{*}{$1.18(0.27,5.20)$} \\
\hline & & & No C & 178 & & 3 & \\
\hline & & & $\mathrm{D}$ & 173 & & 3 & $0.71(0.17,2.95)$ \\
\hline & & & No D & 206 & & 5 & \\
\hline & \multirow[t]{4}{*}{ Taylor (1994) ${ }^{19}$} & \multirow[t]{4}{*}{ Gastric cancer } & $\mathrm{C}$ & 205 & 6 & 6 & \multirow[t]{2}{*}{$2.71(0.55,13.25)$} \\
\hline & & & No $\mathrm{C}$ & 185 & & 2 & \\
\hline & & & $\mathrm{D}$ & 176 & & 4 & $1.22(0.31,4.79)$ \\
\hline & & & No D & 214 & & 4 & \\
\hline Other trials & Lamm $(1994)^{28}$ & & Megadose & 35 & 6 & 14 & $0.50(0.32,0.78)$ \\
\hline & & & Vitamins & 30 & & 24 & \\
\hline & & & $\mathrm{RDA}$ & & & & \\
\hline & Heart Protection Study $(2002)^{30}$ & & Vitamins & 10,269 & 5 & 800 & $0.98(0.89,1.08)$ \\
\hline & & & Placebo & 10,267 & & 817 & \\
\hline
\end{tabular}

*Additional studies for which risk ratios could not be calculated are discussed in the text and displayed in the Evidence Table in Appendix A.

$C$, vitamin C (ascorbic acid) plus additional vitamins; D, vitamin D.

\section{Analysis of Studies Reporting on Colonic Polyps Development}

Eight studies were considered for further analysis of the development of colonic polyps. ${ }^{37-44}$ Four studies were rejected because of insufficient statistics, ${ }^{42,44}$ heterogeneous outcomes, ${ }^{43}$ and duplicate data from another study already included. ${ }^{41}$ Therefore, 4 studies $^{37-40}$ were eligible for pooled analysis as described below.

Combinations of Vitamin C and Vitamin E for Secondary Prevention of Polyp Formation. Two trials ${ }^{37,38}$ of the 4 considered for pooled analysis had treatment arms that involved the combination of vitamin $\mathrm{C}$ and vitamin $\mathrm{E}$ without $\beta$-carotene or vitamin A. Because there were only 2 trials, a pooled analysis was not performed. The risk ratios and 95\% CIs are reported in Table 8 . Neither study reported results significantly different from 1; therefore, there is no evidence that the combinations of vitamin $\mathrm{C}$ and vitamin $\mathrm{E}$ tested are more effective than placebo in the secondary prevention of recurrent adenomatous polyps of the colon.

Trials Featuring Combinations of Vitamin $C$ and Vitamin $E$ with $\beta$ Carotene or Vitamin A for Secondary Prevention of Polyp Formation: Meta-Analysis for the Colonic Polyps Outcome. Three trials ${ }^{37,39,40}$ used combinations of vitamin $\mathrm{C}$ and vitamin $\mathrm{E}$ with carotenoids compared with a placebo. The 3 interventions were considered sufficiently equivalent to allow pooling-even though calcium, which was included in the intervention used in the Hofstad et al. ${ }^{39}$ trial, has activity of its own in prevention of polyp formation, and vitamin A (not $\beta$-carotene) was used in the Roncucci et al. ${ }^{40}$ trial. The estimated relative risks for these 3 studies, along with their 95\% CIs and the pooled estimate, are summarized in Table 9 and in Figure 2.

The pooled estimate yields a relative risk of 0.6 , which is clinically important but not statistically significant $(P=.13)$. The clinically significant results that lack statistical power suggest that more research is needed with larger samples of patients. In addition, the $\chi^{2}$ test of heterogeneity is significant $(P=.001)$, indicating a high degree of heterogeneity among these trials. Sensitivity analyses to account for heterogeneity could not be performed because of the small number of trials, but a visual inspection of Figure 2 suggests that heterogeneity may be because of the differences in patient population selection, in that the baseline rate of new colonic polyps varies greatly between studies. Assessing publication bias with so few trials is difficult at best. The funnel plot showed no obvious bias and formal statistical tests revealed no evidence of a statistically significant bias.

Table 8. Risk Ratios for Polyps for Vitamins C + E vs. Placebo

\begin{tabular}{|c|c|c|c|}
\hline Author (Year) & Intervention & Total $n$ & RR $(95 \% \mathrm{Cl})$ \\
\hline Greenberg $(1994)^{37}$ & $\mathrm{C}+\mathrm{E}$ & 751 & $1.06(0.82,1.37)$ \\
\hline McKeown-Eyssen $(1988)^{38}$ & $\mathrm{C}+\mathrm{E}$ only & 137 & $0.82(0.57,1.18)$ \\
\hline
\end{tabular}

$C$, vitamin $C$ (ascorbic acid); $E$, vitamin $E$ ( $\alpha$-tocopherol). 
Table 9. Pooled Results of Risk Ratios for Polyps Formation for Vitamins C+E with Carotenoids Vs. Placebo

\begin{tabular}{|c|c|c|c|}
\hline Author (Year) & Intervention* & Total $n$ & $\mathrm{RR}(95 \% \mathrm{Cl})$ \\
\hline Greenberg $(1994)^{37}$ & $\mathrm{C}+\mathrm{AT}+\mathrm{BC}$ & 751 & $1.04(0.79,1.36)$ \\
\hline Hofstad $(1998)^{39}$ & $\mathrm{C}+\mathrm{AT}+\mathrm{BC}+\mathrm{Ca}$ & 93 & $0.71(0.50,1.01)$ \\
\hline Roncucci $(1993)^{40}$ & $\mathrm{C}+\mathrm{AT}+\mathrm{A}$ & 209 & $0.16(0.06,0.43)$ \\
\hline Pooled Random Effects Estimate & & & $0.60^{\dagger}(0.31,1.16)$ \\
\hline
\end{tabular}

* $\chi^{2}$ test of heterogeneity $\mathrm{P}-$ value $=.001$.

$A$, vitamin A; AT, $\alpha$-tocopherol; BC, $\beta$-carotene; $C$, vitamin $C$ (ascorbic acid); $C a$, calcium.

\section{CONCLUSIONS}

The results of our literature synthesis show generally disappointing results for the efficacy of these antioxidant supplements in these doses to prevent, modify risks or treat cancer in these populations. The exceptions to this conclusion are a study in which vitamin C (along with other vitamins) was found to be beneficial in preventing new tumors in a single trial of bladder cancer when used in conjunction with $\mathrm{BCG}^{28}$; a study in which vitamin $\mathrm{E}$ when used in combination with $\omega-3$ fatty acid increased survival in patients with advanced cancer ${ }^{26}$; and a study in which vitamin $\mathrm{E}$ for prevention of new tumors in subjects with prostate cancer. ${ }^{27}$ But, in the same study on reduction in new prostate cancer, no effect was seen when vita$\min \mathrm{E}$ and $\beta$-carotene were given together, and there was no effect on death from prostate cancer.

A number of issues potentially limit the effectiveness of this review. Methodologically, there was marked heterogeneity in the size of the population, the intent of the trial, the types of outcomes, and follow-up times. We identified a number of large primary prevention trials $(\alpha$-Tocopherol, $\beta$-Carotene Group, Linxian General Population and Linxian Dysplasia Trials and the Heart Protection Study Collaborative Group) that each reported on a number of separate outcomes. The majority of remaining trials were studies of much smaller numbers of people. They included not only secondary prevention trials but also treatment trials. In addition, the populations varied greatly. The observed heterogeneity in study populations and designs deterred us from conducting a meta-analysis in 2 of our outcome domains-death and new tumors-and also excluded some studies from our colonic polyps analysis. In the face of this heterogeneity, we provide individual study risk ratios and discuss the studies descriptively. With only 2 studies in our primary analysis reporting statistically significant ben-

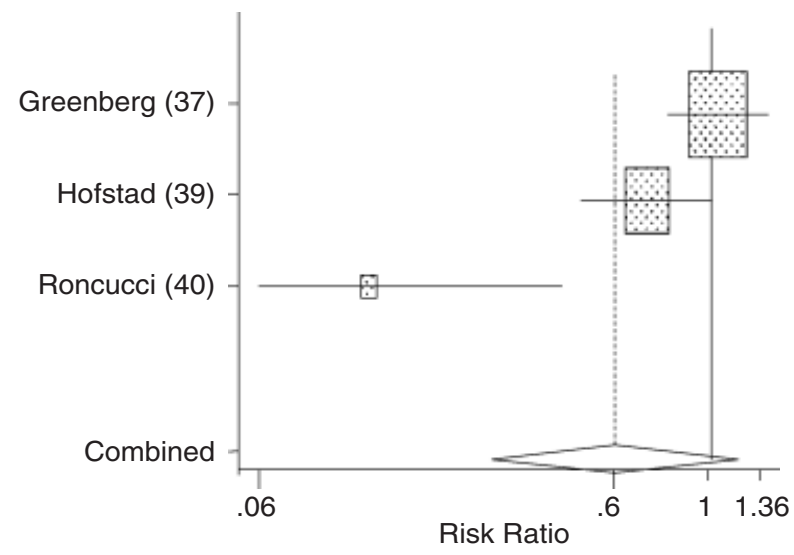

FIGURE 2. Metaanalysis for polyps outcome. eficial results, we could not perform any meaningful sensitivity analysis using study quality. Similarly, we cannot assess the relationship between the possible heterogeneity in treatment effects and study or population characteristics with such small numbers of studies available.

Clinically, a number of potential limitations could be identified as well. Few studies evaluated single agents for efficacy. There was no standard amount of vitamin $\mathrm{C}$ or $\mathrm{E}$ given, nor were the multivitamin formulas consistent from study to study. Some of this variation may be because of differences in the populations assessed; however, it also reflects lack of consensus on recommended doses of these vitamins to be used therapeutically. Given the small number of studies and the differences in doses and formulas, no assessment could be made regarding effectiveness of varying dosage levels or combinations of individual supplements.

During the submission and review of this paper, 2 new major randomized-controlled trials (RCTs) have been published. The first was a study by Lonn et al. ${ }^{45}$ of more than 4,000 patients randomized to receive a daily dose of $400 \mathrm{IU}$ of vitamin $\mathrm{E}$ or placebo and followed for a median of 7 years. No evidence of beneficial effect was observed (incidence $\mathrm{RR}=0.94$, 95\% CI: 0.84-1.06; death $\mathrm{RR}=0.88,95 \% \mathrm{CI}$ : 0.71-1.09).

The second paper was part of the Women's Health Study by Lee et al. ${ }^{46}$ in which 40,000 women were randomized to receive vitamin E (600 IU on alternative days), aspirin or placebo in a factorial design trial. There was no significant effect on the incidence of total cancer $(R R=1.01)$, or for breast cancer $(R R=1.00)$, lung cancer $(R R=1.09)$, or colon cancers $(R R=1.00)$. These findings support the results of our review and metaanalysis.

In trying to resolve the randomized trial results with the cellular/molecular and the epidemiologic data there are several possible explanations: the type of antioxidants used in the trials was different (synthetic vs natural); the dose used was wrong; the results were because of something other than the single antioxidants or combinations that were tested in the trials; the duration of treatment was too short; and unaccounted for confounding means the observed epidemiologic association is not causal.

We conclude that there is no evidence that the antioxidants tested, in the doses tested, and for the populations tested, help prevent cancer. This does not constitute "proof" that antioxidants do not influence cancer, especially in light of the fact that some of the risk ratios were clinically significant but lacked power. This suggests, for these outcomes at least, further studies are needed. However, the generally negative results from the randomized trials do place the burden of proof on the proponents of antioxidant supplements to identify the specific supplement, the dosage, and the population combination that is efficacious. 
This research was conducted by the Southern California Evidence-Based Practice Center based at RAND, Santa Monica, $C A$ under contract to the Agency for Healthcare Research and Quality (AHRQ) (Contract No. 290-97-0001). The research was requested and funded by the National Center for Complementary and Alternative Medicine (NCCAM), National Institutes of Health $(\mathrm{N} I \mathrm{H})$. The authors of this manuscript are responsible for its contents, including any clinical or treatment recommendations. The opinions expressed in this article are those of the authors and do not necessarily reflect the official position of AHRQ, or of NCCAM, NIH, or of the U.S. Department of Health and Human Services. We wish to acknowledge the work of Leigh Rohr, RAND Corporation, in the preparation of this manuscript.

\section{REFERENCES}

1. IOM (Institute of Medicine). Dietary Reference Intakes for Vitamin C, Vitamin E, Selenium, and Carotenoids. Washington, DC: National Academy Press; 2000.

2. Young VR, Newberne PM. Vitamins and cancer prevention: issues and dilemmas. Cancer. 1981;47:1226-40.

3. Block G, Levine M, Vitamin C. A new look. Ann Intern Med. 1991;114:909-10.

4. Blumberg J, Heber D. Multivitamins \& Public Health: Exploring the Evidence. Summary Statement From Multivitamins \& Public Health: Exploring the Evidence; October 1, 2003. Washington, DC: BioScience Communications; 2004

5. Shekelle P, Coulter I, Hardy M, et al. Effect of Supplemental Antioxidants Vitamin C, Vitamin E, and Coenzyme $\mathrm{Q} 10$ for the Prevention and Treatment of Cardiovascular Disease. Evidence Report/Technology Assessment No. 83 (Prepared by Southern California-RAND EvidenceBased Practice Center, Under Contract No. 290-97-0001). AHRQ Publication No. 03-E043.. Rockville, MD: Agency for Healthcare Research and Quality; 2003. Available at: http://www.ahrq.gov/downloads/pub/ evidence/pdf/antioxcan/antioxcan.pdf.

6. Schulz KF, Chalmers I, Hayes RJ, Altman DG. Empirical evidence of bias. Dimensions of methodological quality associated with estimates of treatment effects in controlled trials. JAMA. 1995;273:408-12.

7. Jadad AR, Moore RA, Carroll D, et al. Assessing the quality of reports of randomized clinical trials: is blinding necessary? Control Clin Trials. 1996; 17:1-12.

8. Moher D, Pham B, Jones A, et al. Does the poor quality of reports of randomized trials exaggerate estimates of intervention effectiveness reported in meta-analyses. Lancet. 1998;352:609-13.

9. Microsoft Corporation Microsoft Excel for Windows 2000. Redmond, WA: Microsoft Corporation; 2000.

10. Stata Corporation Stata Statistical Software: Release 6.0. Ver. 6.0. College Station, TX: Stata Corporation; 1999.

11. Alpha-Tocopherol, Beta-Carotene Cancer Prevention Study Group. The effects of vitamin $\mathrm{E}$ and beta-carotene on the incidence of lung cancer and other cancers in male smokers. N Engl J Med. 1994;330: 1029-35.

12. Li J, Taylor P, Li B, et al. Nutrition intervention trials in Linxian, China: multiple vitamin/mineral supplementation, cancer incidence, and disease-specific mortality among adults with esophageal dysplasia. J Natl Cancer Inst. 1993;85:1492-8.

13. Blot W, Li JY, Taylor PR, et al. Nutrition intervention trials in Linxian, China: supplementation with specific vitamin/mineral combinations, cancer incidence, and disease-specific mortality in the general population. J Natl Cancer Inst. 1993;85:1483-92.

14. DerSimonian R, Laird N. Meta-analysis in clinical trials. Control Clin Trials. 1986;7:177-88.

15. Hedges LV, Olkin I. Statistical Methods for Meta-Analysis. San Diego, CA: Academic Press Inc.; 1985.

16. Begg CB, Mazumdar M. Operating characteristics of a rank correlation test for publication bias. Biometrics. 1994;50:1088-101.

17. Egger M, Davey Smith G, Schneider M, Minder C. Bias in meta-analysis detected by a simple, graphical test. BMJ. 1997;315:629-34.

18. Li B, Taylor PR, Li JY, et al. Linxian nutrition intervention trials: design, methods, participant characteristics, and compliance. Ann Epidemiol. 1993;3:577-85.
19. Taylor PR, Li B, Dawsey SM, et al. Prevention of esophageal cancer: the nutrition intervention trials in Linxian, China. Linxian Nutrition Intervention Trials Study Group. Cancer Res. 1994;54:2029s-31s.

20. Albanes D, Virtamo J, Rautalahti M, et al. Pilot study: the US-Finland lung cancer prevention trial. J Nutr Growth Cancer. 1986;3:207-14.

21. Albanes D, Heinonen OP, Taylor PR, et al. Alpha-tocopherol and betacarotene supplements and lung cancer incidence in the alpha-tocopherol, beta-carotene cancer prevention study: effects of base-line characteristics and study compliance. J Natl Cancer Inst. 1996;88:1560-70.

22. Albanes D, Malila N, Taylor PR, et al. Effects of supplemental alphatocopherol and beta-carotene on colorectal cancer: results from a controlled trial (Finland). Cancer Causes Control. 2000; 11:197-205.

23. Blot W. Preventing cancer by disrupting progression of precancerous lesions. J Natl Cancer Inst. 2000;92:1868-9.

24. Creagan ET, Moertel CG, O'Fallon JR, et al. Failure of high-dose vitamin C (ascorbic acid) therapy to benefit patients with advanced cancer. A controlled trial. N Engl J Med. 1979;301:687-90.

25. Creagan ET, Moertel CG, Schutt AJ, Oconnell MJ. Vitamin-c (ascorbic-acid) therapy of pre-terminal cancer-patients. 1979;20:355-6.

26. Gogos CA, Ginopoulos P, Salsa B, Apostolidou E, Zoumbos NC, Kalfarentzos F. Dietary omega-3 polyunsaturated fatty acids plus vitamin $\mathrm{E}$ restore immunodeficiency and prolong survival for severely ill patients with generalized malignancy: a randomized control trial. Cancer. 1998;82:395-402.

27. Heinonen OP, Albanes D, Virtamo J, et al. Prostate cancer and supplementation with alpha-tocopherol and beta-carotene: incidence and mortality in a controlled trial. J Natl Cancer Inst. 1998;90: 414-5.

28. Lamm D, Riggs DR, Shriver JS, vanGilder PF, Rach JF, DeHaven JI. Megadose vitamins in bladder cancer: a double-blind clinical trial. J Urol. 1994;151:21-6.

29. Moertel CG, Fleming TR, Creagan ET, Rubin J, O'Connell MJ, Ames MM. High-dose vitamin $\mathrm{C}$ versus placebo in the treatment of patients with advanced cancer who have had no prior chemotherapy. A randomized double-blind comparison. N Engl J Med. 1985;312:137-41.

30. MRC/BHF Heart Protection Study Collaborative Group. MRC/BHF Heart Protection Study of antioxidant vitamin supplementation in 20536 high-risk individuals: a randomised placebo-controlled trial. Lancet. 2002;360:23-33.

31. Ascorbic acid does not cure cancer. Nutr Rev. 1985;43:146-7.

32. Poulter JM, White WF, Dickerson JW. Ascorbic acid supplementation and five year survival rates in women with early breast cancer. Acta Vitaminol Enzymol. 1984;6:175-82.

33. Rautalahti MT, Virtamo JR, Taylor PR, et al. The effects of supplementation with alpha-tocopherol and beta-carotene on the incidence and mortality of carcinoma of the pancreas in a randomized, controlled trial. Cancer. 1999;86:37-42

34. Virtamo J, Edwards BK, Virtanen M, et al. Effects of supplemental alpha-tocopherol and beta-carotene on urinary tract cancer: incidence and mortality in a controlled trial (Finland). Cancer Causes Control. 2000; 11:933-9.

35. Dawsey SM, Wang GQ, Taylor PR, et al. Effects of vitamin/mineral supplementation on the prevalence of histological dysplasia and early cancer of the esophagus and stomach: results from the Dysplasia Trial in Linxian, China. Cancer Epidemiol Biomarkers Prev. 1994;3:167-72.

36. Varis K, Taylor PR, Sipponen P, et al. Gastric cancer and premalignant lesions in atrophic gastritis: a controlled trial on the effect of supplementation with alpha-tocopherol and beta-carotene. The Helsinki Gastritis Study Group. Scand J Gastroenterol. 1998;33:294-300.

37. Greenberg ER, Baron JA, Tosteson TD, et al. A clinical trial of antioxidant vitamins to prevent colorectal adenoma. N Engl J Med. 1994;331: 141-7.

38. McKeown-Eyssen G, Holloway C, Jazmaji V, Bright-See E, Dion P, Bruce WR. A randomized trial of vitamins $\mathrm{C}$ and $\mathrm{E}$ in the prevention of recurrence of colorectal polyps. Cancer Res. 1988;48:4701-5.

39. Hofstad B, Almendingen $\mathbf{K}$, Vatn $\mathbf{M}$, et al. Growth and recurrence of colorectal polyps: a double-blind, three-year intervention with calcium and antioxidants. Digestion. 1998;59:148-56.

40. Roncucci L, Di Donato P, Carati L, et al. Antioxidant vitamins or lactulose for the prevention of the recurrence of colorectal adenomas. Colorectal Cancer Study Group of the University of Modena and the Health Care District 16. Dis Colon Rectum. 1993;36:227-34.

41. Roncucci L, Ponz de Leon M. Antioxidant vitamins or lactulose as chemopreventive agents for colorectal cancer. In: Waldron K, Johnson I, 
Fenwick G, eds. Food and Cancer Prevention: Chemical and Biological Aspects. Cambridge, UK: Royal Society of Cambridge; 1993:147-50.

42. Bussey HJ, DeCosse JJ, Deschner EE, et al. A randomized trial of ascorbic acid in polyposis coli. Cancer. 1982;50:1434-9.

43. Cahill RJ, O'Sullivan KR, Mathias PM, Beattie S, Hamilton H, O'Morain C. Effects of vitamin antioxidant supplementation on cell kinetics of patients with adenomatous polyps. Gut. 1993;34:963-7.

44. Malila N, Virtamo J, Virtanen M, Albanes D, Tangrea JA, Huttunen JK. The effect of alpha-tocopherol and beta-carotene supplementation on colorectal adenomas in middle-aged male smokers. Cancer Epidemiol Biomarkers Prev. 1999;8:489-93.

45. Lonn E, Bosch J, Yusuf S, et al. HOPE and HOPE-TOO Trial Investigators. Effects of long-term vitamin E supplementation on cardiovascular events and cancer: a randomized controlled trial. JAMA. 2005;293: $1338-47$.

46. Lee IM, Cook NR, Gaziano JM, et al. Vitamin E in the primary prevention of cardiovascular disease and cancer: the women's health study: a randomized controlled trial. JAMA. 2005;294:56-65.

\section{Supplementary Material}

The following supplementary material is available for this article online at www.blackwell-synergy.com

Appendix A. Evidence Table for Antioxidants for Prevention and Treatment of Cancer. 